\title{
KINERJA PELAYANAN APARATUR DALAM SERTIFIKASI TENAGA PENDIDIK DI DINAS PENDIDIKAN KABUPATEN HULU SUNGAI UTARA
}

\author{
M. Husaini \\ Sekolah Tinggi Ilmu Administrasi (STIA) Amuntai \\ Email: muhammadhusaini10081986@gmail.com
}

\begin{abstract}
The objective of this research is to know service performance of the apparatus in the certification of educators in the Education Office of Kabupaten Hulu Sungai Utara and factors affecting the service performance of the apparatus are in the certification of educators in the Education Office of Kabupaten Hulu Sungai Utara. The research method used is a qualitative research method using a descriptive analysis technique, with techniques of documentation and interviews. The informants in obtaining the data are the Head of the Office, Secretary, Chief of Department. Chiefs of Sections, Head of Sub-sections and also the staff at the Education Office of Hulu Sungai Utara.The result showed that the service performance of the apparatus in the certification of educators in the Education Office of Hulu Sungai Utara has not been optimal yet when seen from the actual tasks and functions. Factors affecting are professionalism factor and organizational structure of the financial managers of educators certification in the Education Office of Hulu Sungai Utara. It can be seen from the aspect of the distribution of tasks which is unclear and is still overlapped in the work, as well as other aspects that the authorities have not been fully delegated for employees in accordance with the existing position and title.
\end{abstract}

Keywords: service performance, apparatur, certification of educators

\section{PENDAHULUAN}

Tuntutan daerah dan masyarakat tentang perlunya desentralisasi kekuasaan yang lebih terarah dan terkoordinir pada tingkat provinsi dan kabupaten/kota direspon dengan dikeluarkannya Undang-Undang Nomor 23 Tahun 2014 tentang Pemerintahan Daerah dan Undang-Undang Nomor 33 Tahun 2004 tentang Perimbangan Keuangan antara Pemerintah Pusat dan Pemerintah Daerah, serta Peraturan Pemerintah Nomor 41 Tahun 2007 tentang Organisasi Perangkat Daerah yang ditindak lanjuti dengan ditetapkannya Peraturan Daerah Kabupaten Hulu Sungai Utara Nomor 5 Tahun 2015 tentang Organisasi dan Tata Kerja Dinas Pendidikkan Kabupaten Hulu Sungai Utara dan sebagai pelaksananaannya ditetapkan Peraturan Bupati pasal 43, 44, 45 Tahun 2009 tentang Kedudukan, Tugas, Fungsi dan Tata Kerja Dinas Pendidikan Kabupaten Hulu Sungai Utara dalam melaksanakan program dan kegiatan kependidikan.

Penilaian kinerja bagi aparatur berguna untuk menilai kuantitas, kualitas dan efisiensi, motivasi, dan guna penyesuaian anggaran organisasi. Tetapi persoalannya, apakah penilaian yang dilakukan telah menggambarkan kinerja yang sebenarnya. Hal ini akan sangat ditentukan oleh ketajaman dalam menentukan cakupan, cara dan indikator-indikator yang digunakan. Suatu penilaian yang menggunakan cakupan, cara dan indikator yang sangat terbatas akan memberikan hasil yang sangat terbatas pula dan berarti kurang menggambarkan keadaan yang sebenarnya. Selama ini, penilaian secara sistematik terhadap kinerja aparatur belum menjadi tradisi, sehingga berakibat pada munculnya perdebatan yang tidak terselesaikan ketika terjadi hasil penilaian yang berbeda antara pihak yang satu dengan lainnya.

$\begin{array}{llll}\text { Kinerja yang baik akan } & \text { selalu } \\ \text { bertanggungjawab dengan baik } & \text { setiap } \\ \text { menggunakan atau manfaat } & \text { aset. } & \text { Untuk }\end{array}$


mengukur kinerja aparatur setidak-tidaknya dapat mempertimbangkan dari apa yang telah diadopsi seperti seperti seberapa banyak pekerjaan yang dapat diselesaikan, bagaimana kualitas penyelesaian pekerjaan yang dilakukan, bagaimana kecepatan waktu yang diperlukan dalam penyelesaian suatu pekerjaan, bagaimana sikap perilaku aparatur yang bersangkutan, bagaimana tingkat disiplin aparatur, bagaimana tingkat kesopanan mereka, bagaimana tanggungjawab dalam menjalankan suatu pekerjaan, bagaimana kerjasama dengan tim, bagaimana tingkat inisiatifnya, bagaimana tingkat kesehatannya, bagaimana kerapiannya, bagaimana kepemimpinannya dan bagaimana loyalitas atau ketaatannya dalam bekerja. Dengan demikian diperlukan kinerja yang lebih intensif dan optimal dari aparatur sertifikasi tenaga pendidik pada Dinas Pendidikan Kabupaten Hulu Sungai Utara demi optimalisasi bidang tugas yang diembannya. Kinerja dalam suatu organisasi sangat penting, dengan adanya kinerja maka tingkat pencapaian hasil akan terlihat sehingga akan dapat diketahui seberapa jauh pula tugas yang telah dipikul melalui tugas dan wewenang yang diberikan dapat dilaksanakan secara nyata dan maksimal.

Kinerja aparatur dalam sertifikasi tenaga pendidik di Dinas Pendidikan Kabupaten Hulu Sungai Utara yang telah dilaksanakan dengan tingkat pencapaian tertentu tersebut seharusnya sesuai dengan Visi yakni Mewujudkan Pendidikan Berkualitas Untuk Seluruh Jenjang Pendidikan dan Misinya adalah Meningkatkan mutu dan daya saing pendidikan yang telah ditetapkan sebagai landasan untuk melakukan tugas yang diemban. Dengan demikian kinerja (performance) merupakan tingkat pencapaian hasil atau the degrees of accomplisment.

Tenaga pendidik yang sudah bersertifikasi di Dinas Pendidikan Kabupaten Hulu Sungai Utara berjumlah 1.547 orang, pada jenjang TK berjumlah 160 orang, jenjang SD 1.030 orang, jenjang SMP 186 orang dan jenjang SMA/SMK berjumlah 139 orang. Kemudian untuk pengawas TK/SD berjumlah 17 orang, pengawas SMP 10 orang dan pengawas SMA/SMK berjumlah 6 orang. Sedangkan tenaga pendidik yang belum bersertifikasi di Dinas Pendidikan Kabupaten Hulu Sungai Utara berjumlah 1.378 orang, pada jenjang TK berjumlah 98 orang, jenjang SD berjumlah 817, jenjang SMP 288 orang, dan jenjang SMA/SMK 175 orang.

$$
\text { Aparatur Dinas Pendidikan yang }
$$

melakukan kegiatan sertifikasi guru berjumlah 11 orang yang diantaranya terdiri dari Bupati, Kepala Dinas, Sekretaris, Kepala Bidang PPTK, Kasi Kesejahteraan dan Pengembangan PTK, Kasubag Keuangan dan Kepegawaian, Bendahara, Pembantu Bendahara, Operator Sistem Informasi Manajemen Tunjangan (SIMTUN) PAUDNI/TK, Operator Sistem Informasi Manajemen Tunjangan (SIMTUN) Tunjangan Dikdas (SD dan SMP) dan Operator Sistem Informasi Manajemen Tunjangan (SIMTUN) Tunjangan Dikmen (SMA/SMK) sertifikasi guru.

Dari uraian tersebut di atas, nampak sekali urgensi penelitian yang terletak kinerja aparatur dalam sertifikasi tenaga pendidik di Dinas Pendidikan Kabupaten Hulu Sungai Utara dengan beban kerja yang tinggi, dimana hanya dengan 11 orang mengerjakan hal yang berhubungan dengan sertifikasi pendidik sebanyak 1.547 orang. Ini membuktikan bahwa beban kerja sangat tinggi, untuk itu agar dapat lebih efesien dan efektif dan berkesinambungan serta memberikan kinerja aparatur dalam sertifikasi tenaga pendidik di Dinas Pendidikan Kabupaten Hulu Sungai Utara terencana dengan baik secara aktual dalam sehari-hari, serta untuk mengetahui pentingnya kinerja aparatur dalam sertifikasi tenaga pendidik di Dinas Pendidikan Kabupaten Hulu Sungai Utara dalam melaksanakan tugas pokok dan fungsi (tufoksi) untuk penyelenggaraan pelayanan publik lebih optimal sesuai dengan harapan yang diinginkan. Maka dari itu peneliti berusaha menggali bagaimana kinerja yang dilakukan oleh aparatur dalam sertifikasi tenaga pendidik di Dinas Pendidikan Kabupaten Hulu Sungai Utara dalam pelayanan publik untuk melaksanakan tugas pokok dan fungsi (tufoksi) yang tertuang pada uraian tugas Dinas Pendidikan Kabupaten Hulu Sungai Utara serta melaksanakan Visi yakni Mewujudkan Pendidikan Berkualitas Untuk Seluruh Jenjang Pendidikan dan Misinya adalah Meningkatkan mutu dan daya saing pendidikan yang tertuang dalam rencana strategis (renstra) Dinas Pendidikan Kabupaten Hulu Sungai 
Utara.

\section{TINJAUAN PUSTAKA}

\section{Kinerja}

Menurut Agus Dwiyanto (2006:49) penilaian kinerja birokrasi bpublik tidak cukup dilakukan dengan menggunakan indikator yang melekat pada birokrasi itu, seperti efisiensi dan efektivitas, tetapi juga harus dilihat dari indikator-indikator yang melekat pada pengguna jasa, seperti kepuasan pengguna jasa, akuntabilitas dan responsivitas.

August W. Smith yang dikutif oleh Sedarmayanti (2003:65) dalam bukunya yang berjudul tentang Sumber Daya Manusia (SDM) dan produktivitas kerja menyimpulkan bahwa : kinerja adalah hasil keluaran dari proses.

Menurut Mahsun (2001:12) pengukuran kinerja sektor publik mengartikan kinerja adalah mengenai tingkat pencapaian pelaksanaan suatu kegiatan/program/ kebijakan dalam mewujudkan sasaran, tujuan, misi dan visi organisasi yang tertuang dalam strategis planing suatu organisasi.

Siagin (2003:68) mengatakan bahwa pengertian kinerja adalah keseluruhan kemampuan seseorang untuk bekerja sedemikian rupa sehingga mencapai tujuan kerja secara optimal dan berbagai sasaran yang telah diciptakan dengan pengorbanan secara rasio kecil dibandingkan dengan hasil yang dicapai.

\section{Paradigma Pelayanan Publik}

Menurut Barata (2004:31) pelayanan prima (service excellent) terdiri dari enam unsur pokok, antara lain sebagai berikut : Kemampuan (ability, Sikap (attitude), Penampilan (apperance), Perhatian (attention, Tindakan (action) dan Tanggung jawab (accountability).

Konsep The Old Public Administration ini dalam perjalanan sejarah memperoleh perkembangannya dengan konsep-konsep baru. Salah satunya yaitu konsep rasional, model yang dikemukakan oleh Herbert Simon melalui tulisannya tentang administrative behavior (1957:86).

\section{METODE PENELITIAN}

Jenis penelitian yang digunakan dalam penelitian ini adalah jenis penelitian kualitatif. Pendekatan kualitatif menekankan pada suatu proses, artinya penelitian bermaksud untuk menentukan, memahami, menjelaskan fenomena yang terjadi. Pendekatan tersebut digunakan dengan pertimbangan menyajikan bentuk keseluruhan dalam menganalisa suatu fenomena dan lebih peka menangkap informasi kualitatif deskriptif secara relatif dan tetap berusaha mempertahankan keutuhan (wholeness) dari objek, artinya bahwa data yang dikumpulkan dalam rangka studi kasus dipelajari sebagai keseluruhan yang terintegrasi. Kemudian permasalahan yang mungkin akan timbul dalam penelitian ini akan dideskripsikan sebagai upaya tindak lanjut peranan Dinas Pendidikan Kabupaten Hulu Sungai Utara terhadap kinerja aparatur dalam sertifikasi tenaga pendidik.

Sumber data adalah asal data yang diperoleh dan dipergunakan. Sumber data dalam penelitian ini adalah 1) Data Primer, data primer adalah data penelitian yang diperoleh secara langsung dari sumber data asli dan data dikumpulkan untuk menjawab pertanyaan penelitian yang sesuai dengan keinginan peneliti. 2) Data Sekunder, data sekunder adalah data yang merupakan sumber data penelitian yang diperoleh peneliti secara tidak langsung melalui perantara. Data sekunder umumnya berupa bukti, catatan atau laporan historis yang telah tersusun dalam arsip.

Instrumen Penelitian, Dalam penelitian kualitatif yang akan menjadi instrumen penelitian adalah peneliti itu sendiri. Penelitian kualitatif tidak ada pilihan lain dari pada menjadi manusia sebagai instrumen penelitian. Ini disebabkan segala sesuatu belum mempunyai bentuk yang pasti. Masalah, fokus penelitian, prosedur penelitian, hipotesis yang digunakan bahkan hasil yang akan diperoleh semuanya tidak dapat ditentukan secara pasti dan jelas sebebelumnya. Segala sesuatu masih perlu dikembangkan dalam penelitian tersebut. sehingga tidak ada pilihan lain hanya peneliti itu sendiri sebagai alat untuk mencapainya. Dengan demikian instrumen utama dalam penelitian, akan secara langsung melakukan pengamatan.

Teknik pengumpulan, Penelitian kualitatif 
harus bersifat "perspectif emic" artinya perolehan data bukan sebagaimana seharusnya akan tetapi berdasarkan apa yang terjadi di lapangam dialami, dirasakan dan dipikirkan oleh sumber data. Dalam rangka pengumpulan data dalam penelitian ini ada beberapa proses kegiatan yang dapat dilakukan diantaranya wawancara, pengamatan dan dokumentasi. Wawancara dilakukan dengan cara bertanya atau berkomunikasi secara langsung dengan responden maupun pihak-pihak yang terkait dengan penelitian ini. Mengadakan pengamatan langsung di lokasi penelitian untuk memperoleh gambaran suasana tempat kerja, proses kerja dan hal lain yang diperlukan. Teknik dokumentasi digunakan untuk memperoleh atau melengkapi data yang diperoleh di lapangan.

Analisis data dalam penelitian ini menggunakan model interaktif Miles dan Huberman (2007:247) Data-data yang dikumpulkan dianalisis dalam tiga komponen, yaitu pengumpulan data (proses pengumpulan data hasil dari alat pengumpul data), reduksi data (data yang diperoleh dari hasil observasi, wawancara dan dokumentasi yang disusun sesuai relevansi sistematikanya) dan penyajian data (data yang berbentuk kualitatif ditampilkan dalam bentuk narasi) kemudian membuat suatu kesimpulan.

\section{HASIL DAN PEMBAHASAN}

Menurut Agus Dwiyanto (2006:49) penilaian kinerja birokrasi publik tidak cukup dilakukan dengan menggunakan indikator yang melekat pada birokrasi itu, seperti efisiensi dan efektivitas, tetapi juga harus dilihat dari indikator-indikator yang melekat pada pengguna jasa, seperti kepuasan pengguna jasa, akuntabilitas dan responsivitas.

Penulis memilih indikator yang melekat pada pengguna jasa seperti kepuasan, akuntabilitas dan responsivitas, lebih tepat dan lebih mampu mengukur kinerja pelayanan aparatur dalam sertifikasi tenaga pendidik di Dinas Pendidikan Kabupaten Hulu Sungai Utara.

Kinerja aparatur berguna untuk menilai kuantitas, kualitas dan efisiensi, motivasi, dan guna penyesuaian anggaran organisasi. Tetapi persoalannya, apakah penilaian yang dilakukan telah menggambarkan kinerja yang sebenarnya. Hal ini akan sangat ditentukan oleh ketajaman dalam menentukan cakupan, cara dan indikatorindikator yang digunakan. Suatu penilaian yang menggunakan cakupan, cara dan indikator yang sangat terbatas akan memberikan hasil yang sangat terbatas pula dan berarti kurang menggambarkan keadaan yang sebenarnya. Selama ini, penilaian secara sistematik terhadap kinerja aparatur belum menjadi tradisi, sehingga berakibat pada munculnya perdebatan yang tidak terselesaikan ketika terjadi hasil penilaian yang berbeda antara pihak yang satu dengan lainnya.

Terkait dengan kinerja pelayanan aparatur sertifikasi tenaga pendidik di Dinas Pendidikan Kabupaten Hulu Sungai Utara harus menyesuaikan dengan visi dan misi yang telah dituangkan dalam rencana strategis (renstra) Dinas Pendidikan Kabupaten Hulu Sungai Utara. Kemudian ditungkan dalam sebuah Visi yakni mewujudkan pendidikan berkualitas untuk seluruh jenjang pendidikan dan misinya yakni meningkatkan mutu daya saing pendidikan. Untuk mencapai visi dan misi tersebut, Dinas Pendidikan pada kegiatan sertifikasi tenaga pendidik melaksanakan tahapan seperti sosialisasi, identifikasi, penerimaan berkas, pendidikan dan pelatihan profesi guru dan proses penerbitan sertifikat pendidik.

Kinerja pelayanan aparatur dalam sertifikasi tenaga pendidik di Dinas Pendidikan Kabupaten Hulu Sungai Utara dilihat dari kepuasan pengguna belum optimal. Jika dilihat dari tugas dan fungsi secara aktual yang dilaksanakan sehari-hari dapat dikatakan aparatur belum profesional melaksanakan tugas dan fungsinya dalam memberikan pelayanan, sosialisasi, identifikasi sertifikasi tenaga pendidik, penerimaan berkas sertifikasi dan pelaksanaan pendidikan dan pelatihan profesi guru sertifikasi tenaga pendidik. Dalam hal kinerja aparatur sertifikasi tenaga pendidik dilihat dari kepuasan pengguna jasa, perlu adanya peningkatan keterampilan, kecapan praktis, kompetensi, pengetahuan, keleluasan pengalaman, sikap dan perilaku, kreativitas, moralitas dan lain-lain. Peranan Dinas Pendidikan Kabupaten Hulu Sungai Utara untuk melaksanakan tugas dan fungsinya memberikan 
pengaruh yang terhadap kinerja aparatur dalam memberikan layanan sertifikasi tenaga pendidik sehingga pelayanan yang prima bisa diberikan untuk kepuasan pengguna jasa layanan yang diberikan. Penilaian kinerja dari sisi pengguna jasa menjadi sangat penting karena birokrasi publik juga muncul adanya visi dan misi birokrasi publik, seringkali bukan hanya memiliki stakeholder yang banyak dan memiliki kepentingan yang sering berbenturan satu sama lainnya menyebabkan birokrasi publik mengalami kesulitan untuk merumuskan misi yang jelas. Akibatnya, ukuran kinerja aparatur pelayanan publik di mata para stakeholder juga berbeda-beda. Indikator kinerja aparatur dapat dilihat dari keteraturan dan ketepatan waktu kerja, kepatuhan terhadap aturan dan sistem kerja, kuantitas dan kualitas pekerjaan yang memuaskan, pekerjaan yang dilakukan dengan kualitas dan kuantitas tinggi dapat memuaskan yang bersangkutan dan tempat dia bekerja, penyelesaian pekerjaan dengan semangat yang baik, hubungan dan komunikasi yang efektif, mampu memberikan motivasi dan nilai tambah serta tanggung jawab. Dinas Pendidikan Kabupaten Hulu Sungai Utara merumuskan dan melaksanakan serta mempelajari peraturanperaturan dan petunjuk teknis, pedoman penyusunan program dan kegiatan serta bahanbahan lainnya. Semuanya itu harus disusun dan dihimpun/disiapkan dalam bentuk program kerja dan sistem kerja yang baik. Untuk melaksanakan tugas tersebut Dinas Pendidkan harus membuat suatu persiapan bahan dan data program dan kegiatan sesuai peraturan daerah nomor 31 Tahun 2015 tentang Pembentukan Struktur Ogranisasi dan Tata Kerja Dinas Pendidikan Kabupaten Hulu Sungai Utara. Kinerja pelayanan aparatur dalam sertifikasi tenaga pendidik dilihat dari kepuasaan pengguna jasa bisa dilaksanakan dengan baik dengan catatan menerapkan segala ketentuan dan pedoman yang telah dibuat.

Kinerja pelayanan aparatur dalam sertifikasi tenaga pendidik di Dinas Pendidikan Kabupaten Hulu Sungai Utara dilihat dari akuntabilitas belum juga optimal. Kinerja pelayanan aparatur dalam sertifikasi tenaga pendidik di Dinas Pendidikan tidak menunjukkan bekerja secara bersunggung- sungguh, bekerja sambil bermain game online, tidak ada koordinasi antara staf dan kasi serta kabid dan tidak bertanggung jawab terhadap kegiatan-kegiatan yang berhubungan dengan sertifikasi tenaga pendidik. Pimpinan Dinas Pendidikan Kabupaten Hulu Sungai Utara diwajibkan melakukan proses akuntabilitas terhadap pencapaianya tugas organisasi, menciptakan proses baru untuk mengukur peningkatan produktivitas kerja, dan melakukan reenginering sistem yang merefleksi terhadap kuatnya komitmen pada akuntabilitas publik. Contoh ada suatu pendapat yang menyatakan bahwa kinerja aparatur sertifikasi tenaga pendidik pada Dinas Pendidikan Kabupaten Hulu Sungai Utara yang menyatakan bahwa aparatur tidak sungguh-sungguh dalam melaksanakan sosialisasi, tidak ada koordinasi, standar operasional prosedur tidak sesuai aturan, meskipun tidak dipungkiri masih ada saja kelurahan dari penerima layanan/pengguna jasa. Hal ini tidak terlepas dari kemampuan, sikap, penampilan, perhatian, tindakan dan tanggungjawab aparatur dalam melaksanakan tugasnya. Faktor mempengaruhi kinerja adlah faktor personal/ individu, meliputi : pengetahuan, keterampian, kemampuan, kepercayaan diri, motivasi, dan komitmen yang dimiliki oleh setiap individu. Faktor kepemimpinan, meliputi kualitas dalam memberikan dorongan, semangat, arahan dan dukungan yang diberikan oleh pimpinan. Faktor tim, meliputi kualitas dukungan dan semangat yang diberikan oleh rekan dalam satu tim, kepercayaan terhadap sesama anggota tim, kekompakkan dan keeratan anggota tim. Faktor sistem, meliputi sistem kerja, fasilitas kerja atau infrastruktur yang diberikan oleh organisasi, proses organisasi, dan kultur kinerja dalam organisasi. Faktor kontekstual (situasional) meliputi tekanan dan perubahan lingkungan eksternal dan internal. Kinerja organisasi pada dasarnya tanggung jawab setiap individu yang bekerja dalam organisasi. Oleh sebab itu perlunya Dinas Pendidikan untuk melakukan perubahan menuju pelayanan yang prima yang didukung oleh aparatur kompeten dan memiliki akuntabilitas yang baik.

Kinerja pelayanan aparatur dalam sertifikasi tenaga pendidik di Dinas Pendidikan 
Kabupaten Hulu Sungai Utara dilihat dari responsivitas belum optimal. Dimana aparatur tidak tanggap dalam hal kegiatan sertifikasi tenaga pendidik, tidak tanggap dalam bekerja dan tidak berorientasi kepada penerima layanan. Responsivitas ini mengukur daya tanggap provider terhadap harapan, keinginan, aspirasi serta tuntutan penerima layanan. Responsivitas adalah kerelaan untuk menolong/memberikan layanan kepada publik dan menyelenggarakannya dengan ikhlas. Pelayanan aparatur sertifikasi tenaga pendidik di Dinas Pendidikan Kabupaten Hulu Sungai Utara harus ditingkatkan untuk memaksimalkan layanan yang diberikan. Kinerja seorang aparatur ditentukan oleh bagaimana dia melaksanakan tugas-tugas yang dibebankan kepadanya yang didasarkan atas kecakapan, pengalaman dan kesungguhan serta waktu. Kinerjanya juga dapat dilihat dari hasil kerja secara kualitas dan kuantitas yang dicapai dengan daya tanggap yang baik. Selanjutnya kemampuan seseorang dalam bekerja diciptakan dengan pengorbanan yang secara rasio kecil dibandingkan dengan hasil yang dicapai. Mengenai responsivitas kinerja pelayanan aparatur sertifikasi tenaga pendidikan pada dinas pendidikan perlu ditingkatkan dalam kegiatan layanan sertifikasi tenaga pendidik di Dinas Pendidikan.

Faktor yang mempengaruhi kinerja aparatur dalam sertifikasi tenaga pendidik di Dinas Pendidikan Kabupaten Hulu Sungai Utara yaitu Profesionalisme dan struktur. Faktor profesionalisme, pegawai yang handal tentunya bekerja penuh dedikasi serta bersunggungsungguh menekuni pekerjaan yang dilakukannya. Sebagai pelayan terhadap masyarakat pegawai Dinas Pendidikan Kabupaten Hulu Sungai Utara pada kegiatan sertifikasi tenaga pendidik tidak memiliki kesungguhan dalam melaksanakan tugas dan fungsinya sehari-hari. Pegawai Dinas Pendidikan Kabupaten Hulu Sungai Utara juga tidak didukung kemampuan bekerja yang baik, oleh karena tidak dibekali pendidikan dan pelatihan serta kursus yang berkaitan dengan tugas dan fungsinya sehari-hari. Selanjutnya dalam melaksanakan tugas dan fungsinya Dinas Pendidikan Kabupaten Hulu Sungai Utara tidak memiliki rasa tanggungjawab penuh dalam bidang tugasnya.

Dengan demikian pegawai Dinas Pendidikan Kabupaten Hulu Sungai Utara pada kegiatan sertifikasi tenaga pendidik belum bekerja secara profesional, sehingga menyebabkan rendahnya kinerja yang dilakukannya secara aktual sehari-hari. Dinas Pendidikan Kabupaten Hulu Sungai Utara pada kegiatan sertifikasi tenaga pendidik belum memenuhi kebutuhan pegawai menuju arah profesionalisme, keadaan tersebut mempengaruhi kinerja Dinas Pendidikan Kabupaten Hulu Sungai Utara menjadi rendah, sehingga tugas dan fungsi yang dilaksanakan sehari-hari secara aktual belum optimal. Diharapkan dengan adanya profesionalisme pegawai agar tugas dan fungsi organisasi dapat tercapai tujuannya sesuai dengan misi secara optimal menurut standar tertentu yang telah diharapkan oleh organisasi dan terciptanya good govenance.

Faktor Struktur, struktur organisasi mengatur sumber daya manusia bagi kegiatankegiatan ke arah tujuan. Struktur merupakan cara yang selaras dalam menempatkan manusia sebagai bagian organisasi pada suatu hubungan yang relatif tetap, yang sangat menentukan polapola interaksi, koordinasi dan tingkah laku yang berorientasi pada tugas. Struktur organisasi mempunyai tugas kelompok yaitu kompleksitas, formalisasi dan sentralisasi. Kompleksitas berarti dalam struktur organisasi mempertimbangkian tingkat diferensiasi yang ada dalam organisasi termasuk didalamnya tingkat spesialisasi atau pembagian kerja, jumlah tingkatan dalam organisasi serta tingkat sejauh mana unit-unit organisasi tersebar secara geografis. Formulasi berarti tingkat sejauh mana sebuah organisasi menyadarkan diri kepada peraturan dan prosedur untuk mengatur perilaku dari para pegawainya. Sentralisasi adalah mempertimbangkan dimana letak dari pusat pengambilan keputusan, apakah cenderung setralisasi atau desentralisasi. Pada Dinas Pendidikan Kabupaten Hulu Sungai Utara pada struktur organisasi dalam hal pembagian tugas yang diberikan tidak berdasarkan job yang telah ditentukan, sehingga terjadi tumpang tindih pekerjaan, kemudian kewenangan yang diberikan pimpinan maupun atasan yang ada 
pada Dinas Pendidikan Kabupaten Hulu Sungai Utara pada kegiatan sertifikasi tenaga pendidik belumlah secara penuh diberikan kepada bawahan, dengan demikian belum jelas kewenangan apa yang diberikan kepada bawahan, sehingga bawahan sulit untuk berinovasi dengan baik dalam bidang pekerjaannya. Dan koordinasi yang ada antara pimpinan dengan bawahan pada Dinas Pendidikan Kabupaten Hulu Sungai Utara pada kegiatan sertifikasi tenaga pendidik kurang berjalan dengan baik, karena bawahan kurang respon. Begitu pula koordinasi antara Kepala Seksi yang ada masih kurang harmonis sehingga sering terjadi kelambanan dalam mengerjakan suatu tugas yang harus diselesaikan.

Pengukuran kinerja dalam buku The Government Performance Result Act, James B. Whittaker (1998:24) menyebutkan bahwa pengukuran kinerja merupakan suatu alat manajemen yang digunakan untuk meningkatkan kualitas pengambilan keputusan dan akuntabilitas, serta untuk menilai pencapaian tujuan dan sasaran (goals and objectives). Evaluasi kinerja merupakan analisis dan interprestasi keberhasilan kegagalan pencapaian kinerja, dan sekaligus sebagai suatu proses umpan balik atas kinerja yang lalu dan mendorong adanya perbaikan produktivitas di masa mendatang. Oleh karena itu, evaluasi kinerja pada dasarnya adalah kegiatan penilaian yang dilandasi semangat internal audit untuk mengukur tingkat pencapaian kinerja suatu organsiasi. Selama ini audit yang dilakukan pada lingkup instansi pemerintah terbatas pada audit keuangan (financial audit) dan audit kepatuhan (compliance audit) saja, padahal terdapat juga audit kinerja yang difokuskan kepada kinerja organisasi. Oleh karenanya audit kinerja dengan manajemen kinerja merupakan sarana yang sangat penting pengaruhnya untuk memperbaiki kinerja aparatur di sektor publik. Kedua hal tersebut dapat digunakan untuk memperbaiki proses (efisiensi) dan meningkatkan hasil (efektivitas).

Terkait kinerja aparatur dalam sertifikasi tenaga pendidik di Dinas Pendidikan Kabupaten Hulu Sungai Utara kalau dilihat dari kepuasan pengguna jasa, akuntabilitas dan responsivitas belum optimal. Hal ini dilihat dari kemampuan aparatur pada kegiatan sosialisasi, identifikasi, pendidikan dan pelatihan sertifikasi pendidik. Diharapkan aparatur dapat meningkatkan kemampuannya melalui pendidikan dan pelatihan sehingga profesional dalam bekerja serta perbaikan struktur organisasi yang efektif.

\section{KESIMPULAN}

Berdasarkan uraian diatas dapatlah ditarik kesimpulan sebagai berikut :

1. Kinerja pelayanan aparatur dalam sertifikasi tenaga pendidik di Dinas Pendidikan jika dilihat dari tugas dan fungsi secara aktual yang dilaksanakan sehari-hari dapat dikatakan belum optimal dilihat dari indikator yang melekat pada pengguna jasa seperti kepuasan, akuntabilitas dan responsivitas.

2. Faktor yang mempengaruhi kinerja pelayanan aparatur dalam sertifikasi tenaga pendidik di Dinas Pendidikan yaitu faktor profesionalisme dan faktor struktur yang secara rinci dapat dilihat dari aspek pembagian tugas yang belum jelas dan terdapat tumpang tindih pekerjaan, begitu pula dari aspek kewenangan yang belum sepenuhnya diserahkan kepada pegawai sesuai dengan jabatan dan kurangnya koordinasi dalam pendelegasian tugas.

\section{REFERENSI}

Alwi, Hasan. 2007. Kamus Besar Bahasa Indonesia, Jakarta : Balai Pustaka.

Badan Pusat Statistik. 2015. Hulu Sungai Utara Dalam Angka, Amuntai.

Benveniste, Guy. 1994. Professionalizing the Organization : Reducing Bureaucracy to Enhance Effectiveness, Penterjemah : Sehat Simamora, Grafindo Persada, Jakarta.

Bogdan dan Taylor. 1984. Pengantar Metode Penelitian Kualitatif, Penerbit Usaha Nasional, Surabaya.

Dwiyanto, Agus, Agus Pramusinto \& Yuyun 
Purbokusumo. 1993. Kinerja Organisasi Pelayanan Publik di DIY dan Jateng”, Hasil Penelitian, Fisipol UGM, Yogyakarta.

Faisal, S. 1990. Penelitian Kualitatif DasarDasar dan Aplikasi, YA3, Malang.

Fajar, Arnie. 2006. Peranan Sertifikasi Guru dalam Meningkatkan Profesionalisme Guru, Bandung: Disdik Jawa Barat.

Garna K, Judistira. 2000. Metode Penelitian Sosial dalam Ilmu Pemerintahan, Primaco Akademika, Bandung.

Handoko, T. Hani. 1988. Manajemen Personalia dan Sumber Daya Manusia, Edisi ke 4. Yogyakarta : Liberty.

........., 2001. Manajemen Personalia dan Sumber Daya Manusia Edisi ke 4. Yogyakarta : Liberty.

Hendrasti, Lily N. 1990. Wacana No.1, Ánalisis Faktor Yang Dipertimbangkan Mutu Pelayanan, Program Pasca Sarjana Universitas Brawijaya, Malang.

Jaitun. 2013. Kinerja Aparatur Desa Dalam Penyelenggaraan Pemerintah Desa di Desa Sepala Dalung Kecamatan Sesayap Hilir Kabupaten Tana Tidung, eJournal Pemerintahan Integratif, 2013, 1 (1): 13-27.

Karta, Ginandjar. 1995. Tantangan Administrasi Negara : Peningkatan Pelayanan Masyarakat Dalam Era Globalisasi, dalam Manajemen Pembangunan 11/III, LAN-RI, Jakarta.

Lukman, Sampara. 1998. Widyapraja No.13, Reformasi Pelayanan Publik Dalam Menghadapi Era Globalisasi, IIP Depdagri, Jakarta.

Makmur Syarif. 2008. Pemberdayaan Sumber Daya Manusia dan Efektifitas Organisasi, Penerbit PT Raja Grafindo Persada, Jakarta.

Manullang. M. 1995. Manajemen Kepegawaian di Indonesia, Jakarta : Gunung Agung.
Moleong, Lexy J. 1999. Metodologi Penelitian Kualitatif, cetakan kesepuluh, Remaja Rosdakarya, Bandung.

Moenir. 1992. Manajemen Pelayanan Umum, Jakarta : Bumi Aksara.

Nagui, Roland. 1994. Pengembangan Produksi dan Sumber Daya Manusia, Jakarta : PT Grafindo Persada.

Nazir, Mohammad. 2013. Metode Penelitian, Ghalia Indonesia, Jakarta.

Novandy, Riwan. 2009. Analisis Persepsi Masyarakat Terhadap Kualitas Pelayanan Publik Pada Bagian Administrasi Kemasyarakatan dan Kesejahteraan Rakyat Pemerintah Kabupaten Simalungun. Medan : Tesis.

Rahmayanti, Emi. 2015. Implementasi Kebijakan Sertifikasi Guru Sekolah Dasar di Kecamatan Keritang Kabupaten Indragiri Hilir Tahun 2012, Journal Jom Fisip Vol 2 No.1 Februari 2015.

Suharsimi, Arikunto. 2005. Manajemen Penelitian, Cetakan Ketujuh, Penerbit Rineka Cipta, Jakarta.

Tono. 2014. Hubungan Sertifikasi Guru dengan Kinerja Guru Sekolah Dasar Negeri Kecamatan Sebuku Kabupaten Nunukan, eJournal Administrasi Negara, 2 (4), 2014 : 1866 - 1877.

Undang-Undang Nomor 33 Tahun 2004. Tentang Perimbangan Keuangan antara Pusat dan Daerah

Undang-Undang Republik Indonesia Nomor 14 Tahun 2005. Tentang Guru dan Dosen, 2006, Jakarta : Eka Jaya.

Undang-Undang Nomor 23 Tahun 2014. Tentang Pemerintahan Daerah, 2014, Jakarta. 